\title{
PRODUCTION TECHNOLOGY AND MECHANICAL PROPERTIES OF A NEW GRADE OF STEEL FOR FORGINGS WITH INCREASED STRENGTH AND IMPACT STRENGTH
}

\author{
TECHNOLOGIA PRODUKCJI ORAZ WEAŚCIWOŚCI MECHANICZNE NOWEGO \\ GATUNKU STALI NA ODKUWKI O PODWYŻSZONEJ WYTRZYMAEOŚCI \\ I UDARNOŚCI
}

\begin{abstract}
The study involved the development of the basics of production technology and the testing of the mechanical properties of a new grade of steel for forgings with increased strength and impact strength, intended for special products. The scope of the tests included a proposal for a new steel composition along with the production of ingots and its further processing into forgings in industrial conditions, using an input with various dimensions of the cross-section, proposed as a result of numerical calculations, including the performance of heat treatment in two variants. As a result of tests and analyses, it was found that the proposed technology enables the production of semi-finished products with the assumed level of strength and impact strength.
\end{abstract}

Keywords: low-alloy steel, hot forging, forging, strength, impact strength

\section{INTRODUCTION}

The subject of the article is a material with potential application for the production of forgings for artillery shell bodies. Currently, the $45 \mathrm{H} 1$ steel grade is widely used for bodies, which is characterised by the following properties after heat treatment: tensile strength $R_{\mathrm{m}}=1000 \pm 50 \mathrm{MPa}$, yield strength $R_{\mathrm{p} 0.2}=900 \pm 50 \mathrm{MPa}$, reduction $Z=\min .45 \pm 2 \%$ and impact strength $\mathrm{KCU}=54 \pm 5 \mathrm{~J} / \mathrm{cm}^{2}$. Due to the necessity to use the bodies in changing climatic conditions, it is necessary to determine impact strength $\mathrm{KV}$ at $-40^{\circ} \mathrm{C}$ (a more strict criterion than impact strength KCU2); therefore, in the framework of previously performed studies, this parameter was determined for steel $45 \mathrm{H} 1$ and the average impact strength was obtained at the level of $16 \mathrm{~J}$ [1, 2]. The analysis of the steel for HE (high explosive) projectile bodies currently used in NATO countries shows that in order to obtain the proper fragmentation effect, a steel with the minimum mechanical properties listed in Table 1 is required $[1,2]$.
Opracowano podstawy technologii produkcji oraz przeprowadzono badania wtaściwości mechanicznych nowego gatunku stali na odkuwki o podwyższonej wytrzymatości i udarności z przeznaczeniem dla wyrobów specjalnych. Zakres badań obejmowat propozycję nowego składu stali wraz z wykonaniem wlewków $i$ jej dalszym przetwarzaniem na odkuwki $w$ warunkach przemystowych, wykorzystujac wsad o różnych wymiarach przekroju poprzecznego zaproponowanych $w$ wyniku obliczeń numerycznych tacznie $z$ wykonaniem obróbki cieplnej $w$ dwóch wariantach. W wyniku badań $i$ analiz stwierdzono, że zaproponowana technologia umożliwia uzyskanie pótwyrobów o założonym poziomie wytrzymałości i udarności.

Stowa kluczowe: stal niskostopowa, kucie na goraco, odkuwka, wytrzymatość, udarność
In Poland, the basic materials for artillery shell bodies are defined by the Russian standard GOST W 10230-75. It covers three grades: $45 \mathrm{H} 1,45 \mathrm{H} 3$ and S-60. Steels $45 \mathrm{H} 1$ and $45 \mathrm{H} 3$ are low-alloy steels containing carbon at the level of $0.40-0.50 \%$ and chromium at the level of $1.10-1.40 \%$ and $2.40-2.90 \%$, respectively. The $45 \mathrm{H} 1$ steel has a chemical composition similar to the domestic $45 \mathrm{H}$ steel grade according to $\mathrm{PN}-89 / \mathrm{H}-84030 / 04$, while the $45 \mathrm{H} 3$ steel has no equivalent in domestic standards. The S-60 steel is a high-quality high-carbon steel with a C content of $0.55-0.65 \%$, the domestic equivalent of which is grade 60 produced according to $\mathrm{PN}-93 / \mathrm{H}-84019$. The domestically produced fragmenting steels $(45 \mathrm{H} 1,45 \mathrm{H} 3$ and S-60) are not able to achieve the properties indicated in Table 1 without their thorough modification (chemical composition and production technology).

As a result of the project, the foundations of the domestic technology of manufacturing artillery shells made of a new fine-grained steel, which, compared to the $45 \mathrm{H} 1$ steel, are characterised by higher strength and yield strength (at least $200 \mathrm{MPa}$ ), higher impact strength $\mathrm{KV}$ at $-40^{\circ} \mathrm{C}$ (by min. 
Table 1. Requirements for a new grade of fine-grained steel for the production of HE bodies

Tabela 1. Wymagania dla nowego gatunku stali drobnoziarnistej do wytwarzania kadłubów HE

\begin{tabular}{|c|c|c|c|c|c|c|}
\hline \multirow[t]{2}{*}{$\begin{array}{c}\text { Requirements } \\
\text { Wymagania }\end{array}$} & $\begin{array}{c}R_{\mathrm{P} 0,2} \\
{[\mathrm{MPa}]}\end{array}$ & $\begin{array}{c}\boldsymbol{R}_{\mathrm{m}} \\
{[\mathrm{MPa}]}\end{array}$ & $\begin{array}{c}A_{5} \\
{[\%]}\end{array}$ & $\begin{array}{c}Z \\
{[\%]}\end{array}$ & $\begin{array}{c}\mathrm{U}-40^{\circ} \mathrm{C} \\
\text { ISO-V, [J] }\end{array}$ & $\begin{array}{c}\text { Hardness } \\
\text { Twardość } \\
\text { HRC }\end{array}$ \\
\hline & $\min .1000$ & $\min .1200$ & $\min .8$ & $\min .35$ & $\min .27$ & $\min .37$ \\
\hline
\end{tabular}

$10 \mathrm{~J}$ ), which shall contribute to the improvement of effective fragmentation.

\section{SAMPLE MATERIAL}

Based on the research carried out as part of the project [2] and subsequent research by Łukasiewicz - IMŻ [3-5], guidelines were developed as to the chemical composition of artillery bodies made of steels that meet NATO requirements (Tab. 1). Steel marked with the symbol 47HGMV was proposed [4]. Three new grades of steel were produced as part of the project, which were obtained using a vacuum induction furnace in the line for semi-industrial physical simulation of industrial processes at Łukasiewicz - IMŻ. The chemical compositions of the melts were in accordance with the requirements specified in studies $[4,5]$. A high repeatability of the content of individual elements was obtained, especially those determining the properties of the final products, i.e. C, Mn, Cr, Mo and V. Additionally, low levels of harmful admixed elements: $\mathrm{P}, \mathrm{S}$ and $\mathrm{Cu}$, and gases were obtained. Laboratory ingots with a weight of several dozen $\mathrm{kg}$ and cross-sectional dimensions of $140 \times 140-160 \times 160 \mathrm{~mm}$, and their further processing by hot forging and pressing methods in industrial conditions allow for the highly probable conclusion of the possibility of using this material produced in a full industrial cycle, starting from the continuous band casting process with a similar range of cross-sectional dimensions. Further works are planned to produce the input material for the production of bodies in industrial conditions.

\section{ANALYSIS OF HOT FORGING PARAMETERS FOR BODY FORGINGS USING THE FINITE ELEMENT METHOD}

\subsection{INPUT DATA FOR NUMERICAL SIMULATIONS}

The purpose of the analysis was to determine whether the current technology of producing forgings for bodies can be modified in terms of the selection of the dimensions of the input's cross-section, due to the availability of steel products on the market. If the material with standard dimensions was used, the cost of producing the body forgings would be much lower, and the availability of the material would be much higher. In the current body production technology, the input is a bar with a square cross-section with a $115 \mathrm{~mm}$ side. The bar's dimensions were selected so that the input's diagonal was $136 \mathrm{~mm}$. Fig. 1 shows selected dimensions (length, radius of curvature, diagonal) of standard sizes of bars manufactured in Poland, which were selected for the numerical analysis of the forging process.

The numerical simulations were carried out with the use of the Qform3D program. The following input parameters were used:

- input: 47HGMV steel

- input form: bars with square cross-section, side dimensions: $110 \mathrm{~mm}$ and $115 \mathrm{~mm}$
- input weight: $31.5 \mathrm{~kg}$

- input heating temperature: $1100^{\circ} \mathrm{C}$

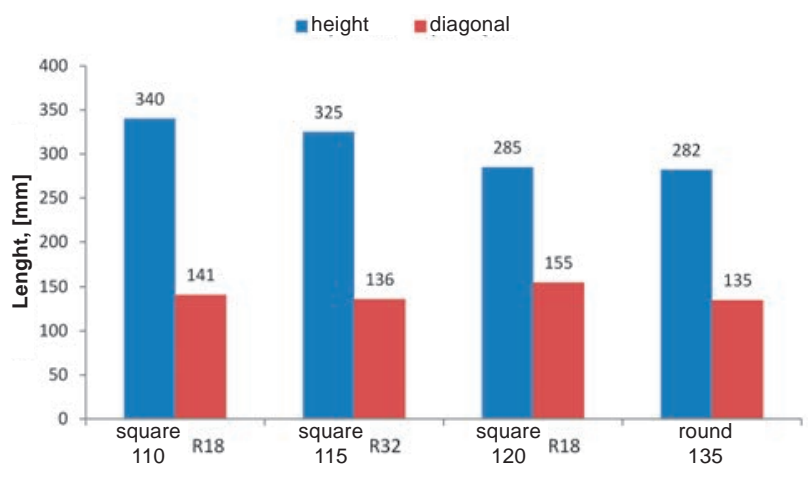

Fig. 1. Dimensions of analysed bars

Rys. 1. Wymiary prętów poddanych analizie

- hydraulic press with a pressing force of $800 \mathrm{~T}$, punch movement rate: $40 \mathrm{~mm} / \mathrm{s}$

- lubrication: graphite.

\subsection{MATERIAL FLOW ANALYSIS}

Due to the different dimensions of the bar sections with the same set of forging tools, the start of hot forging took place each time with a different position of the punch, as shown in Fig. 2. Due to the deformation at the same punch rate, the forging time was varied. The forging of a $120 \mathrm{~mm}$ square bar was the longest, and the shortest - a bar with a round cross-section. Fig. 3 shows the flow of the material in the form of a round bar after 1, 2 and 3 seconds. It was found that in each variant of the shape of the input, the material moved smoothly and no laps or external defects occurred.

\subsection{TEMPERATURE DISTRIBUTION ANALYSIS}

A comparison of the temperature distribution on the longitudinal section of the forgings is shown in Fig. 4. There were no significant differences in any of the variants. The temperature during the entire forging process was correct from the point of view of the plasticity of the material necessary to achieve the correct final shape.

\subsection{FORGING SHAPE ANALYSIS}

The shape of the forgings is a representation of the stamp-die assembly, taking into account the thermal expansion of the material. During deformation, no laps or failure to fill the cut-out was found. The material deformed in a similar manner for all types of input. However, due to the different size of the cross-sectional area and the forging time, shape defects, the so-called 'shackle', occurred in the upper part of the forgings (Fig. 5). It was found that from the point of view of minimising the occurrence of shape 


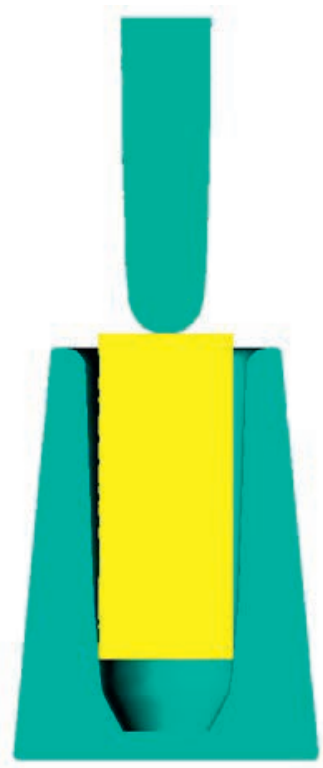

square 110

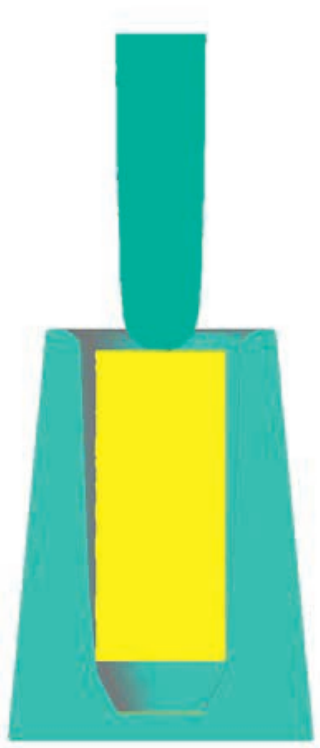

square 115

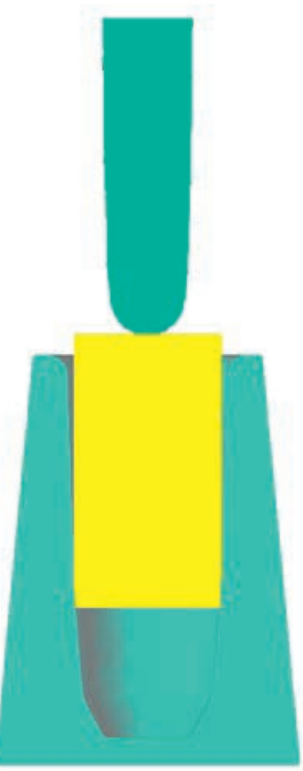

square 120

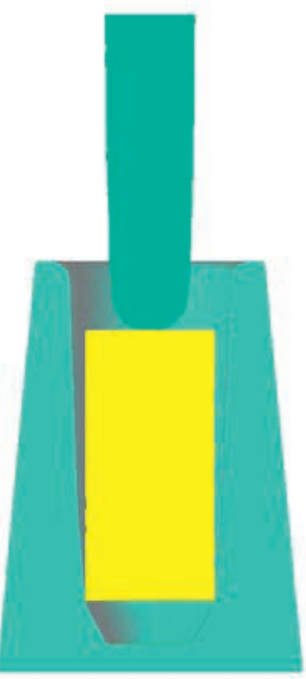

round 135

Fig. 2. Punch location in the initial phase of forging

Rys. 2. Usytuowanie stempla w początkowej fazie kucia

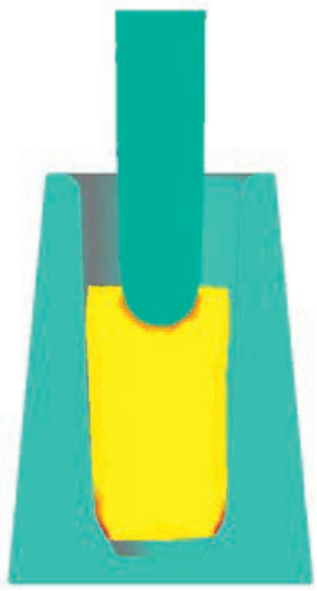

a)

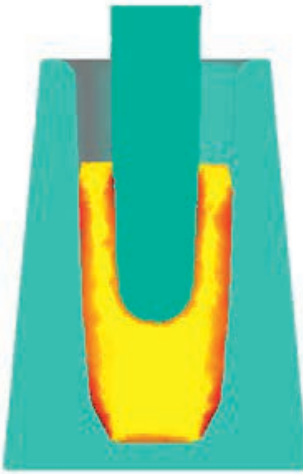

b)

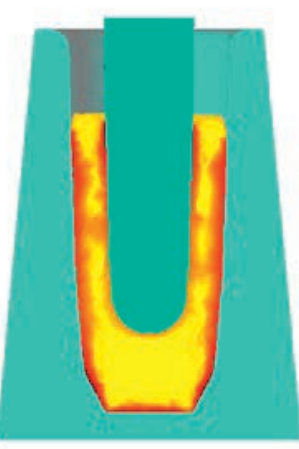

c)

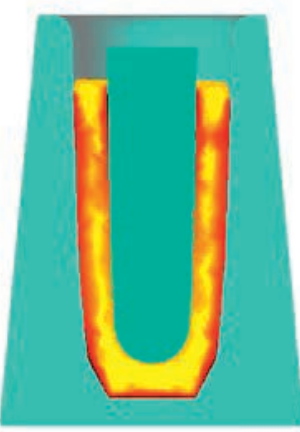

d)

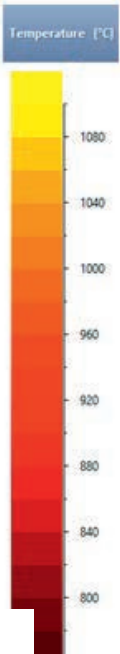

Fig. 3. Course of material flow during hot forging of $135 \mathrm{~mm}$ round bars: a) after $1 \mathrm{~s}$, b) after $2 \mathrm{~s}$, c) after $3 \mathrm{~s}$, d) final state Rys. 3. Przebieg płynięcia materiału w czasie kucia na gorąco prętów okr. $135 \mathrm{~mm}$ : a) po $1 \mathrm{~s}$, b) po $2 \mathrm{~s}$, c) po 3 s, d) stan końcowy

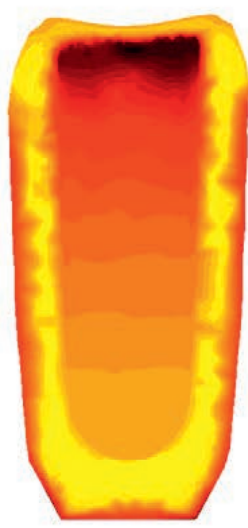

square 110

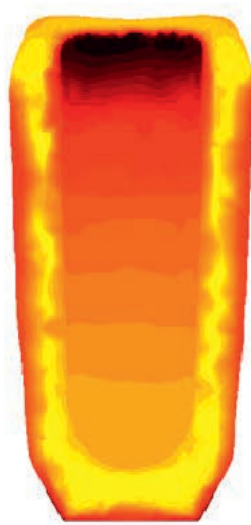

square 115

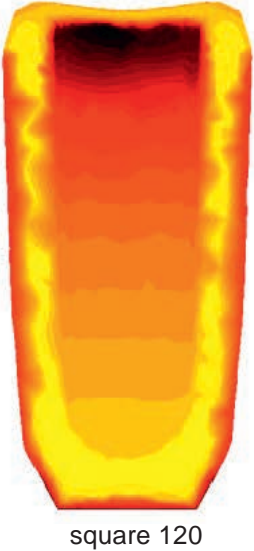

square 120

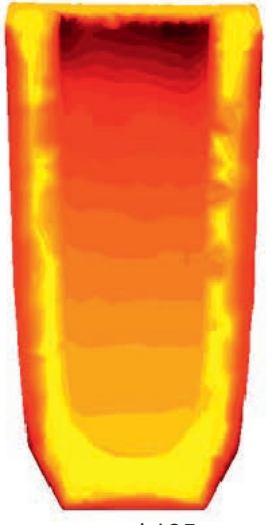

round 135

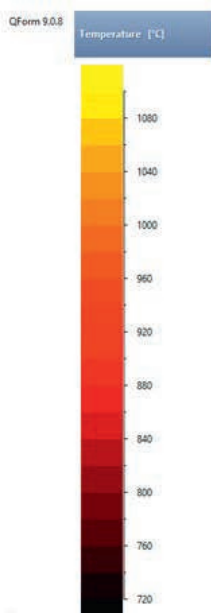

Fig. 4. Temperature distributions on the longitudinal section of forgings Rys. 4. Rozkłady temperatury na przekroju wzdłużnym odkuwek 


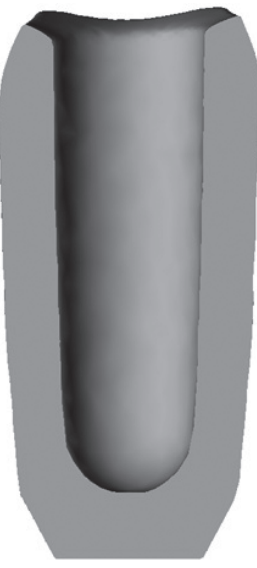

square 110

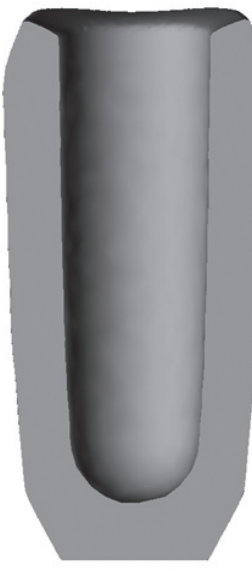

square 115

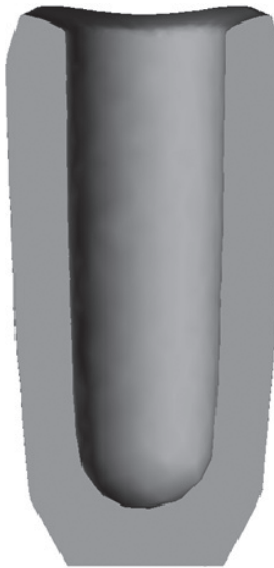

square 120

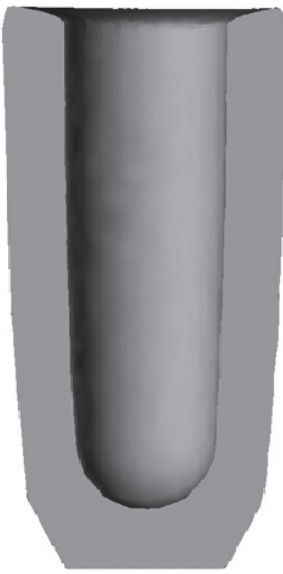

round 135

Fig. 5. Cross-section of the forgings after hot forging

Rys. 5. Przekrój poprzeczny odkuwek po kuciu na gorąco

defects the most advantageous forging input is a bar with a round cross-section.

\subsection{FORCE PARAMETERS OF THE HOT FORGING PROCESS}

Fig. 6 shows the distribution of the punch pressure depending on the forging time. The value of the maximum pressing force is similar in all variants. However, its course is variable. Due to the shortest section of the bar and its circular cross-section (similarly to the die), the forging time for round bars is the shortest, which means that the hydraulic press works with greater loads for a longer time than when forging $110 \mathrm{~mm}$ or $120 \mathrm{~mm}$ square bars. For this reason, it is more advantageous to use $110 \mathrm{~mm}$ or $120 \mathrm{~mm}$ square bars as input than $115 \mathrm{~mm}$ square or round bars.

It is similar with the total work of deformation of the forging process. The maximum value of the deformation work exceeds $400 \mathrm{~kJ}$ and is similar for all variants, but its implementation in a shorter time means that then the power required for deformation is the highest.

\subsection{SELECTION OF THE OPTIMAL VARIANT FOR INDUSTRIAL TESTS}

Taking into account that industrial tests were carried out with the use of the current set of tools (punch, die, and tooling) and taking into account the stability of the hot forging process and the potential availability of the input, it was recommended to forge sections of $110 \mathrm{~mm}$ and $115 \mathrm{~mm}$ square bars as a reference variant in industrial tests.

\section{MANUFACTURE OF EXPERIMENTAL SEMI-FINISHED PRODUCTS FOR BODIES IN INDUSTRIAL CONDITIONS}

\subsection{FABRICATION OF INPUT BARS FOR THE FORGING PROCESS}

According to the results of numerical simulations, $110 \mathrm{~mm}$ square bars with a diagonal of approx. $140 \mathrm{~mm}$ were prepared from three semi-industrial steel melts of the 47HGMV

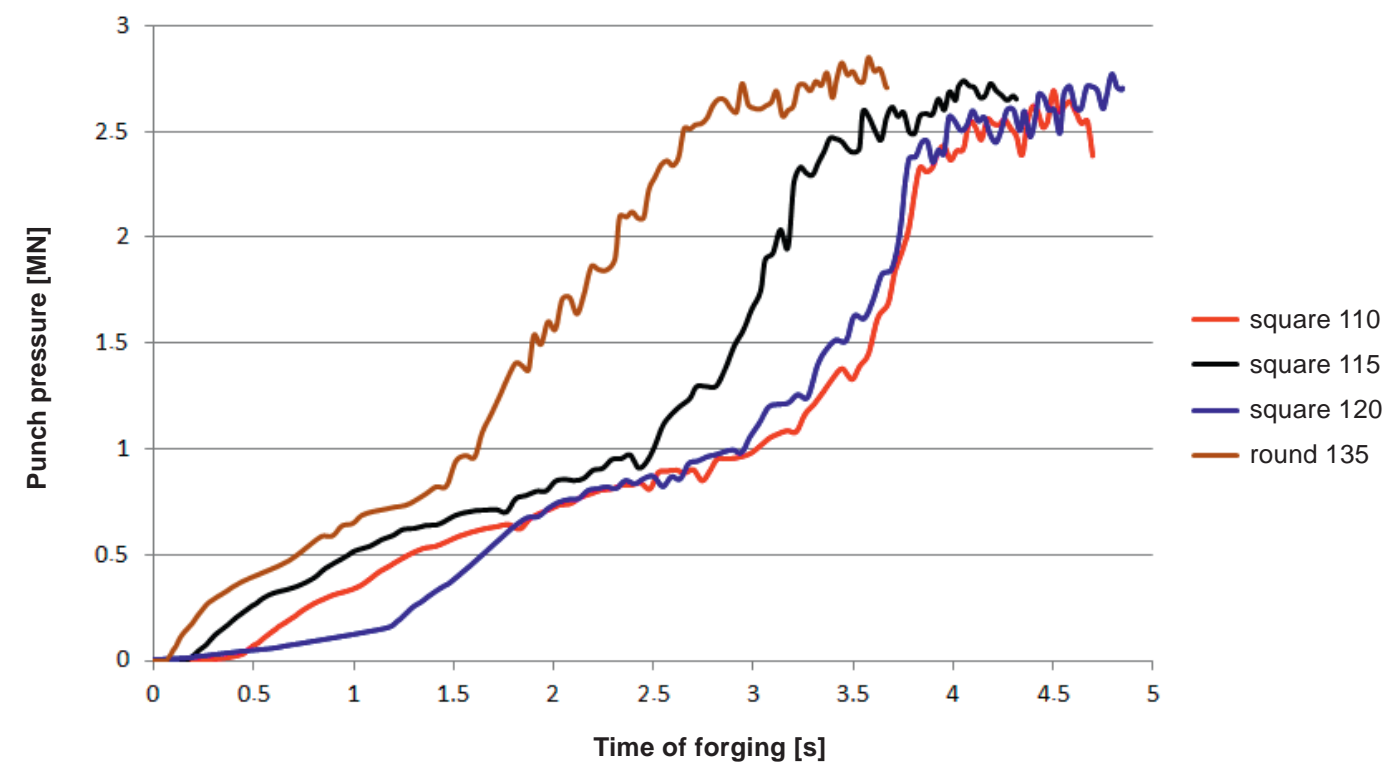

Fig. 6. Punch pressure distribution during forging Rys. 6. Rozkład sił nacisku stempla w czasie kucia 
grade using the free form hot forging method (Fig. 7) and cut to lengths corresponding to the assumed weight. In order to obtain forgings for the bodies, sections of $115 \mathrm{~mm}$ square bars with a diagonal of approx. $135 \mathrm{~mm}$ were also prepared (Fig. 8), obtained as part of another study.

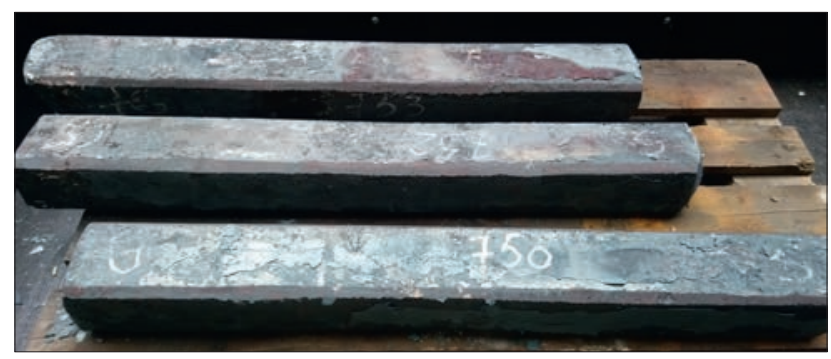

Fig. 7. 110 square bars after free forging

Rys. 7. Pręty kw. 110 po kuciu swobodnym

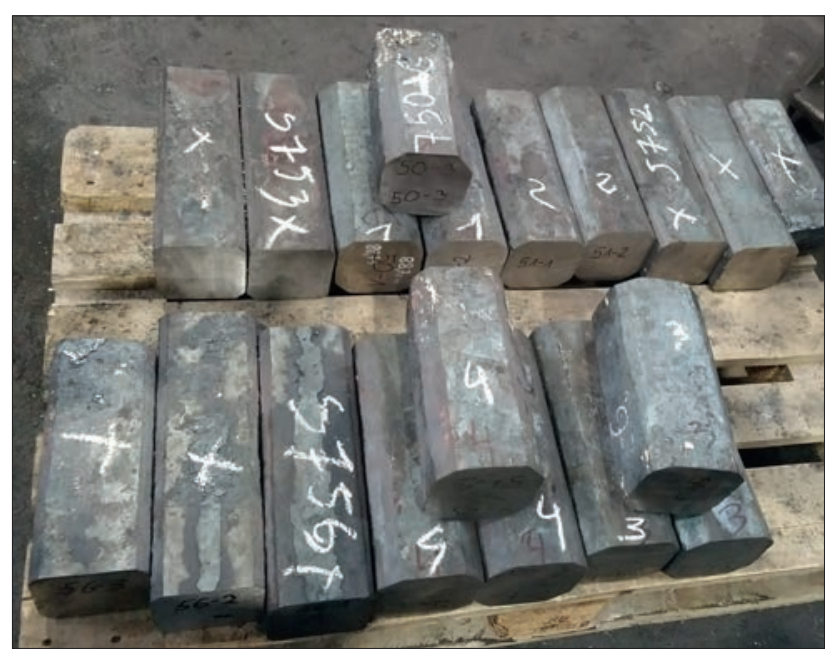

Fig. 8. Sections of bars intended for forging for semi-finished products for bodies

Rys. 8. Odcinki prętów przeznaczone do kucia odkuwek na półwyroby na kadłuby

\subsection{PRODUCTION OF FORGINGS USING HOT FORGING}

The forging for bodies took place in industrial conditions. Sections of the $110 \mathrm{~mm}$ square bars were induction heated to approx. $1200^{\circ} \mathrm{C}$, and then placed in the forging die and subjected to the process of sinking in one procedure and drawing the wall in the second procedure. The forgings were made correctly. During the forging of $110 \mathrm{~mm}$ square bars, no differences were found in the deformation process, both during sinking and drawing the wall, compared to forging forgings from $115 \mathrm{~mm}$ square bars. All the forgings were found to be suitable for the next step of producing semi-finished products for the shell bodies.

\section{RESULTS OF THE EXAMINATION OF MECHANICAL PROPERTIES AND STRUCTURE}

The tempering curves of the 47HGMV steel were developed in laboratory conditions in order to obtain optimal mechanical properties and impact strength. Based on the research results, parameters of the industrial process of quenching and tempering of forgings for special products were proposed. The heat treatment of the semi-finished products was carried out in two variants differing in the tempering temperature within the range of $520-580^{\circ} \mathrm{C}$. Tables 2 and 3 show the results of the tests of mechanical properties, impact strength and hardness. Impact strength was determined on standard $10 \mathrm{~mm} \times 10 \mathrm{~mm} \times 55 \mathrm{~mm}$ samples with a V-notch. $\phi 8 \mathrm{~mm} \times \mathrm{M} 12$ samples were prepared for measurement in a static tensile test.

The applied tempering temperatures turned out to be too little differentiated in terms of the obtained mechanical properties and impact strength. In the subsequent tests, higher tempering temperatures should be used in order to increase the impact strength and reduce the mechanical properties, which are much higher than the current requirements for the $45 \mathrm{H} 1$ steel $\left(R_{\mathrm{m}}>980 \mathrm{MPa}, Z>30 \%\right)$. The obtained results of tests of mechanical properties, impact strength and hardness confirmed the great potential of the

Table 2. Results of measurement of mechanical properties of semi-finished products for special products Tabela 2. Wyniki pomiarów właściwości mechanicznych półwyrobów na wyroby specjalne

\begin{tabular}{|c|c|c|c|c|c|}
\hline $\begin{array}{c}\text { Steel melt } \\
\text { identification } \\
\text { Oznaczenie wytopu } \\
\text { stali }\end{array}$ & $\begin{array}{c}\text { Tempering temperature } \\
\text { Temperatura } \\
\text { odpuszczania } \\
{\left[{ }^{\circ} \mathrm{C}\right]}\end{array}$ & $\begin{array}{l}\text { Apparent yield } \\
\text { strength } \\
\text { Umowna granica } \\
\text { plastyczności } \\
\text { [MPa] }\end{array}$ & $\begin{array}{l}\text { Tensile strength }= \\
\text { Wytrzymałość na } \\
\text { rozciaganie } \\
{[\mathrm{MPa}]}\end{array}$ & $\begin{array}{l}\text { Total elongation } \\
\text { Wydłużenie } \\
\text { całkowite } \\
A_{5},[\%]\end{array}$ & $\begin{array}{l}\text { Reduction } \\
\text { Przewężenie } \\
\text { Z, [\%] }\end{array}$ \\
\hline \multirow{3}{*}{ S750 } & \multirow{3}{*}{$\mathrm{T} 1$} & 1246 & 1342 & 10.7 & 61 \\
\hline & & 1261 & 1357 & 10.2 & 58 \\
\hline & & 1254 & 1350 & 10.45 & 60 \\
\hline \multirow{3}{*}{ S752 } & \multirow{3}{*}{$\mathrm{T} 2$} & 1199 & 1297 & 11.5 & 43 \\
\hline & & 1199 & 1293 & 12.0 & 44 \\
\hline & & 1199 & 1295 & 11.75 & 44 \\
\hline
\end{tabular}

Table 3. Results of measurement of impact strength and hardness of semi-finished products for special products Tabela 3. Wyniki pomiarów udarności i twardości półwyrobów na wyroby specjalne

\begin{tabular}{|c|c|c|c|c|c|c|}
\hline \multirow{3}{*}{$\begin{array}{c}\text { Steel melt identification } \\
\text { Oznaczenie wytopu stali }\end{array}$} & \multirow{3}{*}{$\begin{array}{l}\begin{array}{l}\text { Tempering temperature } \\
\text { Temperatura odpuszczania } \\
{\left[{ }^{\circ} \mathrm{C}\right]}\end{array} \\
\mathrm{T} 1 \\
\end{array}$} & \multicolumn{4}{|c|}{$\begin{array}{c}\text { Impact strength } \square \text { Udarność } \\
\mathrm{KV},[\mathrm{J}]\end{array}$} & \multirow{3}{*}{$\begin{array}{c}\begin{array}{c}\text { Hardness average } \\
\text { Twardość średnio } \\
\text { HV10 }\end{array} \\
415 \\
\end{array}$} \\
\hline & & \multicolumn{2}{|c|}{$-40^{\circ}$} & \multicolumn{2}{|c|}{$+20^{\circ}$} & \\
\hline & & 19 & 20 & 33 & 36 & \\
\hline S752 & $\mathrm{T} 2$ & 19 & 21 & 43 & 44 & 401 \\
\hline
\end{tabular}


proposed steel for use in the production of special products. Similar results of the study on mechanical properties were obtained in papers $[1,4]$, which also confirmed the good performance properties of this type of steel.

Figs. 9 and 10 show the structures of semi-finished products for 47HGMV steel bodies after tempering at temperatures in the range of $520-580^{\circ} \mathrm{C}$. It was found in both cases that the structure of a 47HGMV steel body after tempering consists entirely of tempered martensite. The type of microstructure produced ensures the required level of impact strength. In particular, there are no major precipitates along former austenite grain boundaries and in the material's matrix, and the structure is uniform throughout the samples volume. The grain size of former austenite is an important feature of the microstructure and has a significant impact on impact strength. In this study, based on the available literature data [1, 4], the austenitising temperature at which austenite grains do not grow was used. Research on austenite grain size will be continued on an industrial material.

\section{SUMMARY}

The article presents research work to develop the foundations of the domestic manufacturing technology for forgings for artillery shell bodies made of a new finegrained steel, which, compared to the currently used $45 \mathrm{H} 1$
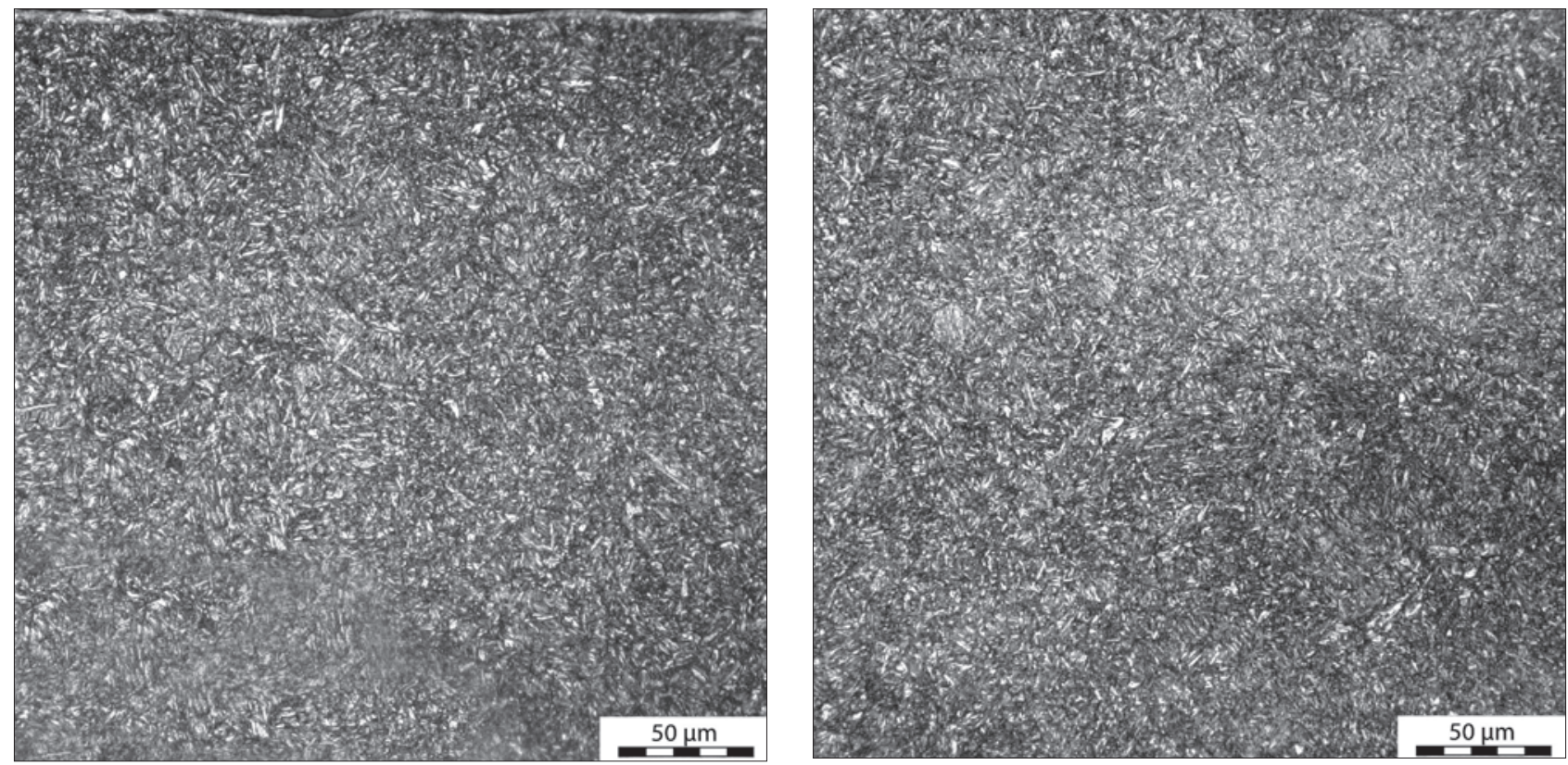

Fig. 9. Structure on the body wall thickness from melt S750 after tempering at temp. T1, magn. 1000x Rys. 9. Struktura na grubości ścianki kadłuba z wytopu $S 750$ po odpuszczaniu w temp. T1, pow. 1000×
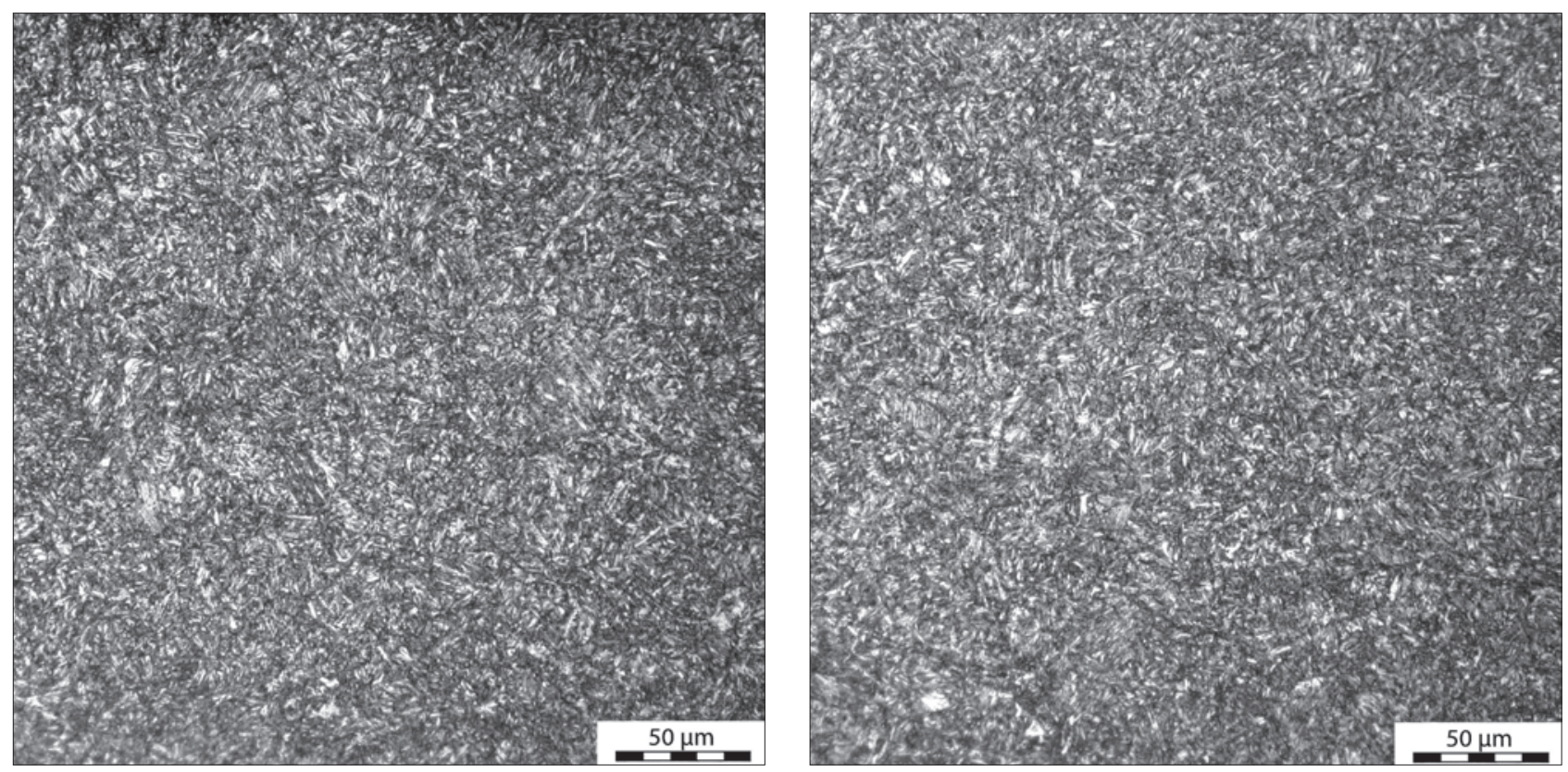

Fig. 10. Structure on the body wall thickness from melt S752 after tempering at temp. T2, magn. 1000x Rys. 10. Struktura na grubości ścianki kadłuba z wytopu $S 752$ po odpuszczaniu w temp. T2, pow. 1000× 
grade, is characterised by higher strength properties and higher impact strength KV. Based on literature data $[1,4]$ and own experience, a new chemical composition of the steel grade designated as 47HGMV was proposed and 3 ingots were cast from this steel under the conditions of the semi-industrial line at Łukasiewicz - IMŻ.

Numerical simulations of the process of hot forging of input for shell bodies were carried out in accordance with the current technology and with the use of an alternative input. It was found that, due to the stability of the forging process and the potential availability of the input, the best input material for industrial tests would be bars with a square cross-section of $110 \mathrm{~mm}$. Industrial trials of forging semi-finished products for bodies were carried out using $110 \mathrm{~mm}$ square and $115 \mathrm{~mm}$ square bars as a reference variant. It was found that the proposed $110 \mathrm{~mm}$ square in- put is fully suitable for hot forging of the above-mentioned products.

The tempering curves of the 47HGMV steel were developed in order to obtain optimal mechanical properties and impact strength. Based on the research results, parameters of the industrial process of quenching and tempering of semi-finished products for bodies were proposed. The heat treatment of the semi-finished products was carried out in two variants differing in the tempering temperature. The obtained results for mechanical properties and impact strength confirmed the great potential of the proposed steel for use in the production of ingots for artillery projectile bodies. The obtained strength, elongation and impact strength values indicate the possibility of adjusting the tempering parameters in order to meet the functional properties of the products.

\section{REFERENCES}

[1] J. Stępień, L. Starczewski. Opracowanie podstaw produkcji w kraju kadłubów artyleryjskich pocisków odłamkowo-burzących dużych kalibrów (do $155 \mathrm{~mm}$ ) spełniających wymagania NATO. In: $V I^{\text {th }}$ International Armament Conference "Scientific Aspects of Armament Technology”. Waplewo 11-13 December 2006, p. 913-921.

[2] L. Starczewski, J. Stępień, R. Nyc. Research Project Report No. PB 0T00C 007 25: "Opracowanie podstaw technologii produkcji $w$ kraju kadłubów artyleryjskich pocisków odłamkowo-burzacych dużych kalibrów (do 155 mm), spetniajacych wymagania NATO”. Sulejówek 2005. [unpublished].
[3] J. Stępień. Research Project Report B-01168/BW/2004 ordered by Wojskowy Instytut Techniki Pancernej i Samochodowej: "Opracowanie charakterystyk trzech modelowych stali oraz wykonanie wytopów próbnych". Gliwice 2004. [unpublished].

[4] J. Stępień. Stal na skorupy pocisków artyleryjskich. Prace Instytutu Metalurgii Żelaza, 2007, 58 (3), p. 1-5.

[5] L. Starczewski, J. Stępień. Stal stopowa do wytwarzania korpusów pocisków. Patent application No. P.401401. 29 December 2012.

[6] M. Burdek, J. Marcisz, J. Stępień, P. Różański. Research Project Report No. S0-1007 "Technologia produkcji oraz wtaściwości mechaniczne nowego gatunku stali na korpusy fragmentujace”. Gliwice 2020. [unpublished]. 